\title{
Developing Situation of Tea Harvesting Machines in Taiwan
}

\author{
Chia-Chang $\mathrm{Wu}$ \\ Tea Machinery \\ Tea Research and Extension Station \\ Taoyuan, Taiwan, R.O.C. \\ tds311@ttes.gov.tw
}

\begin{abstract}
In recent years rapid social change and industrial and commercial development in Taiwan has lead to migration of rural labor, population ageing, high wages and labor shortages, which resulted in significant problems for the tea industry. Thus, mechanization in the tea industry emerges as the direction for the future. According to a survey, tea harvesting and tea manufacturing use $87 \%$ and $5 \%$ of available labor, so the mechanization of tea harvesting is a priority. The application and development of tea harvesting machines worldwide and especially in Taiwan in recent years is investigated in this paper. Recommendations are made for the implementation of tea harvesting machinery in Taiwan in the future. This report may also used as a reference for the use of mechanical harvesting.
\end{abstract}

\section{Keywords- tea; plucking; machine; tea harvesting}

\section{INTRODUCTION}

Taiwan is the sole producer of non-fermented tea, partially fermented tea and completely fermented tea in the world. In 2013, the value of primary processed tea was NT\$6.7 billion. The sum of the value of tea-related marketing and connected industry (such as, leisure, arts, cultural and creative and tourism) of bonus is estimated to be more than NT\$30 billion. With canned tea drinks and tea shops, the total is more than NT\$70 billion. In recent years tea has become the most competitive agricultural product. Social changes have affected the industry and migration of young people from the countryside resulted to a gradual ageing of the labor pool and a labor shortage in tea producing areas. Wages have also increased, so the production and manufacturing costs have increased. Therefore, the introduction of machinery emerges as a necessity for the tea harvesting industry in order to reduce the dependence on labor and costs.

Tea production, manufacturing and marketing are highly labor-intensive. Harvesting and transportation labor is intensive In the tea production process, including tea plantation reclamation, planting, cultivation, irrigation, fertilization, pest and disease control, weed control and pruning. In tea leaf processing, fresh leaves are withered in the sun, set and tossed indoors, fermented, stirred, rolled, dried, de-stemmed, roasted and packaged, which requires much labor and capital.
According to a Chinese academic report, the cost in working hours for tea harvesting accounts for $45 \%$ and $50-60 \%$ of tea production and management [1]. According to a survey by the Taiwan Tea Experiment Station in 2014, the tea industry is especially in need of labor. The manual harvesting of tea accounts for $87 \%$ and tea manufacturing accounts for $5 \%$. The greatest shortage of labor occurs in April and May, so there is a seasonal lack of labor. The report also shows that tea production costs account for $40 \%$, with labor expenditure for tea harvesting accounting for $80 \%$. The time at which tea is harvested affects the quality and price of tea, so labor availability. Labor shortages, aging workforce and increasing wages result to mechanical harvesting becoming rather important for the tea production and manufacturing processes. Japan has the highest penetration of tea harvesting machines. In Taiwan, the Mingjian tea area in Nantou and the northern part of the Pinglin tea area have used mechanical harvesting for many years with good results. In China, Sri Lanka and India mechanical harvesting also increased gradually.

This study focuses on the tea producing countries of the world, the harvesting machinery and its use for systemic collation. The study shows that Taiwanese tea plantations should increase their mechanical harvesting in the future. This paper aims to serve as a reference for agricultural authorities during policy setting and also as a guide for tea plantations managers and farmers.

\section{THE STUDY AND APPLICATION OF TEA HARVESTING MACHINES}

Taiwan, China, Japan, India and Kenya are the major producers of tea harvesting machinery. Japan is the biggest and most advanced producer. Japan was the first country to use mechanical plucking for tea, when the big scissor was introduced in 1910. In 1915 the patent was approved and in 1920 the spreader big scissor was used in tea plantations. In 1960, a self-propelled tea plucking machine and a ride-on tea plucking machine were designed. Some more specialized teas in the Yulu tea plantation were still hand-plucked, but the mechanical plucking of tea accounted for almost $90 \%$ of all tea plucked in Japanese tea plantations. By 1980, tea plantations were commonly using tea plucking machines and the quantity 
of tea plucking machine reached 10, 0000 [2-4]. Using tea plucking machines significantly increased the productivity, reduced the dependence on labor and the production costs.

In 1960, China began to consider the use of tea plucking machines and later studies concerned the cutting, fracture, folding and rolling of plucked tea leaves. Manual, saddlemaneuvered and manually dragged tea machineries were subjected to experiments. By the 1980s, Chinese manufacturers began to study double type plucking machines. However, single and double tea plucking machinery remains all imported [3]. In 1929, Russia imported plucking shears from Japan and in 1930 developed a reciprocating cut tricycle-type tea plucking machine. In 1953, studies began to focus on tea plucking machines and in 1965 a self-propelled tea plucking machine was developed but it was only suitable for use on plains with gradients less than 10 degrees and on gently sloping tea plantations. Therefore, it could only be used in $40 \%$ of plantations. In 1970, a cutting tea plucking machine was developed.

Taiwan began to use the big scissor in 1951. It replaced the manual plucking of tea leaves and was being widely used in Longtan and Yangmei, in northern Taiwan, by 1957. The big scissor only allowed $120 \mathrm{~kg}$ of leaves to be plucked, and it was a difficult task, so its use was not that widespread [5]. The tea experiment station in Pingzhen (The predecessor of Taiwan Tea Experiment Station) introduced a single burden Japanese tea plucking machine in 1964. The farmer used the single tea plucking machine instead of the big scissor for tea leaf plucking. Funding came from the Joint Commission on Rural Reconstruction (The predecessor of Council of Agriculture) and 42 Japanese single reciprocating tea plucking machines were introduced in 1970. In 1973, experiments took place involving reciprocating and rotary type double tea plucking machines. These machines plucking replaced manual plucking in tea plantations in Dongshan, Pinglin and Lugu counties from 1983 to 1985 [4].

In order to reduce the operating costs for the double type plucking machine, the Taiwan Tea Experiment Station introduced a Japanese rail operating system in 1992. At the same time the rail operating material and the operation vehicles were localized and the system was used in the Mingjian tea plantation [6].

\section{MECHANICAL TEA HARVEST EXPERIMENTS}

A comprehensive analysis of the literature on tea harvesting machine experiments from 1996-2014 follows. The harvesting efficiency of different harvesting machines, the pruning operation period, the cost of management operations for machine harvesting and manual harvest of tea and the efficiency of rail mounted machines are detailed. This is a comprehensive and authoritative guide to the use of harvesting machines in tea plantations.

\section{A. A comparison of the harvesting efficiency of different harvesting machines}

Chang [7] compared the efficiency of manual plucking and machine plucking (Big scissor, Ochiai type tea plucking machine, Uchida type tea plucking machine and Fujimi type tea plucking machine) for different types of tree crown (mountain type, semicircular type and level type). The weight of the tea harvest for different plucking methods was determined and it was found that the harvesting efficiency of power plucking machines is greater than that for manual plucking (Table I). The results showed that the Ochiai type tea plucking machine (rotary cutting type), the Uchida type tea plucking machine and the Fujimi type tea plucking machine were 5-8 times more efficient than manual plucking. The Fujimi type plucking machine rotates more slowly than the Ochiai type tea plucking machine (rotary cutting type) and the Uchida type tea plucking machine. The results show that manual tea plucking is more labor intensive and incurs greater production costs than machine plucking. These studies clearly show that in tea plantations, mechanization improves harvesting and increases production. The best results were obtained using a dynamic tea plucking machine that used the reciprocating cutting method. This increased the quality of tea bud selection and avoided coarseness that is associated with old leaves (data not shown). The report stated that the intense vibration of the machine induced operator fatigue so improving the performance of tea plucking machines would be crucial.

TABLE I. A COMPARISON OF THE EFFICIENCY OF DIFFERENT HARVESTING METHODS IN G/MIN (SOURCE: AN ADAPTATION OF [7])

\begin{tabular}{|c|c|c|c|c|c|}
\hline $\begin{array}{c}\text { Plucking } \\
\text { Surface }\end{array}$ & $\begin{array}{c}\text { Manual } \\
\text { harvest }\end{array}$ & $\begin{array}{c}\text { Plucking } \\
\text { Shears }\end{array}$ & $\begin{array}{c}\text { Orgiaii } \\
\text { plucking } \\
\text { machine }\end{array}$ & $\begin{array}{c}\text { Ugita } \\
\text { plucking } \\
\text { machine }\end{array}$ & $\begin{array}{c}\text { Fuji } \\
\text { Plucking } \\
\text { machine }\end{array}$ \\
\hline $\begin{array}{c}\text { Triangular } \\
\text { plane }\end{array}$ & $21.64^{*}$ & 74.11 & 142.00 & 132.75 & 110.50 \\
\hline $\begin{array}{c}\text { Hemispherical } \\
\text { plane }\end{array}$ & 17.42 & 67.53 & 159.00 & 144.25 & 94.67 \\
\hline $\begin{array}{c}\text { Horizontal } \\
\text { plane }\end{array}$ & 24.00 & 83.10 & 162.00 & 176.25 & 99.78 \\
\hline
\end{tabular}

B. The effect of a transition from manual plucking to mechanical plucking in terms of yield and tea quality

Hung et al. [8] evaluated the transition from manual plucking to mechanical plucking in Pinglin and Mingjian. The feasibility of a tea plantation's transition from manual to mechanical plucking is shown in the second year's data. Manual plucking of tea after shaping was necessary before mechanical plucking, because the density of tea buds must be uniform, so the yield of fresh tea leaves increased (Table II). In terms of quality, tea buds do not grow uniformly in the Pinlin tea area, so the tea evaluation scores after manufacturing were lower than those for the mechanical plucking experimental area, but the scent was similar for manually harvested and mechanically harvested tea in both areas (Tables III and IV). Mechanical plucking allows more centralization and fresh tea leaves can be withered indoors, so leaf moisture evaporates uniformly, which results in a better fragrance. For a large area and flat terrain in the Mingjian tea area, manual plucking and mechanical plucking should produce more significant differences. Hung et al. concluded that a transition from manual plucking to mechanical plucking was possible, but its feasibility depended on the manner in which the tea was grown and mechanical plucking required the formation of a curved plucking crown [8]. 
TABLE II. THE EFFECT OF DIFFERENT HARVESTING METHODS ON THE WEIGHT OF FRESH TEA LEAVES HARVESTED IN KG/EXPERIMENT AREA (SOURCE: AN ADAPTATION OF [8])

\begin{tabular}{|c|c|c|c|c|}
\hline \multirow{2}{*}{$\begin{array}{c}\text { Crop } \\
\text { season }\end{array}$} & \multicolumn{2}{|c|}{ Pyng Len } & \multicolumn{2}{c|}{ Ming Jian } \\
\cline { 2 - 5 } & $\begin{array}{c}\text { Machine } \\
\text { harvest }\end{array}$ & $\begin{array}{c}\text { Manual } \\
\text { harvest }\end{array}$ & $\begin{array}{c}\text { Machine } \\
\text { harvest }\end{array}$ & $\begin{array}{c}\text { Manual } \\
\text { harvest }\end{array}$ \\
\hline Spring & 37.3 & 29.7 & 108.4 & 120.0 \\
\hline Summer & 26.1 & 16.8 & 109.4 & 94.4 \\
\hline Autumn & 34.5 & 30.0 & 90 & 80 \\
\hline Winter & 22.8 & 21.6 & 47 & 42 \\
\hline
\end{tabular}

TABLE III. THE EFFECT OF DIFFERENT HARVESTING METHODS ON THE QUALITY OF TEA (PYNG LEN) (SOURCE: AN ADAPTATION OF [8])

\begin{tabular}{|c|c|c|c|c|c|c|c|}
\hline $\begin{array}{c}\text { Crop } \\
\text { season }\end{array}$ & Harvest & $\begin{array}{c}\text { Appea } \\
\text { rance } \\
\mathbf{( 2 0 \% )}\end{array}$ & $\begin{array}{c}\text { Color } \\
\mathbf{( 2 0} \mathbf{)})\end{array}$ & $\begin{array}{c}\text { Color of } \\
\text { liquid } \\
\mathbf{( 1 0 \% )}\end{array}$ & $\begin{array}{c}\text { Aroma } \\
\mathbf{8} \text { \&aste } \\
\mathbf{( 3 0 \% )}\end{array}$ & $\begin{array}{c}\text { Tea } \\
\text { dregs } \\
\mathbf{( 1 0 \% )}\end{array}$ & $\begin{array}{c}\text { Total } \\
\text { scores } \\
\mathbf{( 1 0 0 \% )}\end{array}$ \\
\hline \multirow{2}{*}{ Spring } & Machine & 16.0 & 15.5 & 16.2 & 24.2 & 8.3 & 80.5 \\
\cline { 2 - 8 } & Manual & 16.5 & 16.5 & 16.5 & 24.5 & 8.5 & 82.5 \\
\hline \multirow{2}{*}{ Summer } & Machine & 13.5 & 13.0 & 14.5 & 19.5 & 6.8 & 67.3 \\
\cline { 2 - 8 } & Manual & 14.2 & 14.2 & 15.0 & 20.0 & 7.5 & 70.9 \\
\hline \multirow{2}{*}{ Autumn } & Machine & 14.0 & 14.0 & 15.5 & 19.5 & 7.2 & 70.2 \\
\cline { 2 - 8 } & Manual & 14.6 & 14.5 & 15.0 & 21.5 & 7.2 & 72.2 \\
\hline \multirow{2}{*}{ Winter } & Machine & 15.0 & 15.0 & 16.0 & 22.0 & 7.8 & 75.8 \\
\cline { 2 - 8 } & Manual & 14.0 & 14.5 & 15.2 & 20.5 & 7.2 & 71.4 \\
\hline
\end{tabular}

TABLE IV. THE EFFECT OF DIFFERENT HARVESTING METHODS ON THE QUALITY OF TEA (MING JIAN) (SOURCE: AN ADAPTATION OF [8])

\begin{tabular}{|c|c|c|c|c|c|c|c|}
\hline $\begin{array}{c}\text { Crop } \\
\text { season }\end{array}$ & Harvest & $\begin{array}{c}\text { Appea } \\
\text { rance } \\
\mathbf{( 2 0 \% )}\end{array}$ & $\begin{array}{c}\text { Color } \\
\mathbf{( 2 0} \mathbf{)})\end{array}$ & $\begin{array}{c}\text { Color of } \\
\text { liquid } \\
\mathbf{( 1 0 \% )}\end{array}$ & $\begin{array}{c}\text { Aroma } \\
\mathbf{8 t a s t e} \\
\mathbf{( 3 0 \% )}\end{array}$ & $\begin{array}{c}\text { Tea } \\
\text { dregs } \\
\mathbf{( 1 0 \% )}\end{array}$ & $\begin{array}{c}\text { Total } \\
\text { scores } \\
\mathbf{( 1 0 0 \% )}\end{array}$ \\
\hline \multirow{2}{*}{ Spring } & Machine & 15.0 & 15.0 & 15.0 & 22.8 & 7.8 & 74.6 \\
\cline { 2 - 8 } & Manual & 15.5 & 15.5 & 15.0 & 23.0 & 7.8 & 76.8 \\
\hline \multirow{2}{*}{ Summer } & Machine & 14.8 & 15.0 & 14.8 & 21.3 & 6.8 & 72.7 \\
\cline { 2 - 8 } & Manual & 15.0 & 15.2 & 15.0 & 21.8 & 7.2 & 74.2 \\
\hline \multirow{2}{*}{ Autumn } & Machine & 15.8 & 16.0 & 15.5 & 22.5 & 7.5 & 77.3 \\
\cline { 2 - 8 } & Manual & 15.8 & 15.5 & 14.8 & 21.0 & 7.2 & 74.3 \\
\hline \multirow{2}{*}{ Winter } & Machine & 15.8 & 16.2 & 15.8 & 23.0 & 7.5 & 78.3 \\
\cline { 2 - 8 } & Manual & 15.6 & 15.8 & 15.8 & 23.5 & 7.5 & 78.2 \\
\hline
\end{tabular}

\section{The effect on leaf quality of pruning at different times}

Lee [9] investigated the effects of pruning tea at different times: in winter (a week after the winter solstice) and spring (a week after spring tea plucking). The crown continued to be pruned (depth of pruning is $5 \mathrm{~cm}$ ) at Chin Shin Oolong (Camellia sinensis (L.) O. kuntz) tea plantation and the height and growth of the crown were measured during the harvesting period. Table V shows the results for crown pruning operations in winter and spring. The height of the tea plant and the crown in the manual plucking experimental tea area show less significant differences. The experimental area that used machine plucking for pruning operations in winter or spring, also showed less significant differences in the height of the tea plant and the crown. The height of the plant increased by 1.2$1.5 \mathrm{~cm}$, and the crown was larger by $2.1-2.7 \mathrm{~cm}$ in the mechanical plucking area than in the manual plucking area. The density of tea buds affects yield and quality, so this must be controlled within a certain range. A large number of tall plants could cause a nutrient shortage, which would result in smaller tea buds and thinning. A smaller density of buds can result excessive vegetative growth in plant and the quality of the fresh leaves is lower.
TABLE V. A COMPARISON OF THE HEIGHT AND WIDTH OF TEA BUSHES IN CM (SOURCE: AN ADAPTATION OF [9])

\begin{tabular}{|c|c|c|c|c|c|c|}
\hline \multirow{2}{*}{ Treatment } & \multicolumn{2}{|c|}{$\begin{array}{c}\text { After pruning } \\
\text { the previous year }\end{array}$} & \multicolumn{2}{c|}{$\begin{array}{c}\text { Before pruning } \\
\text { current year }\end{array}$} & \multicolumn{2}{|c|}{ Total growth } \\
\cline { 2 - 7 } & $\begin{array}{c}\text { Bush } \\
\text { height }\end{array}$ & $\begin{array}{c}\text { Bush } \\
\text { width }\end{array}$ & $\begin{array}{c}\text { Bush } \\
\text { height }\end{array}$ & $\begin{array}{c}\text { Bush } \\
\text { width }\end{array}$ & $\begin{array}{c}\text { Bush } \\
\text { height }\end{array}$ & $\begin{array}{c}\text { Bush } \\
\text { width }\end{array}$ \\
\hline \multicolumn{7}{|c|}{ Manual harvest } \\
\hline $\begin{array}{c}\text { Prune after } \\
\text { winter tea }\end{array}$ & 54.2 & 106.8 & 59.5 & 111.8 & 5.3 & 5.0 \\
\hline $\begin{array}{c}\text { Prune after } \\
\text { spring tea }\end{array}$ & 54.6 & 104.8 & 60.0 & 108.9 & 5.4 & 4.1 \\
\hline \multicolumn{7}{|c|}{ Machine harvest } \\
\hline $\begin{array}{c}\text { Prune after } \\
\text { winter tea }\end{array}$ & 54.9 & 104.3 & 61.7 & 111.4 & 6.8 & 7.1 \\
\hline $\begin{array}{c}\text { Prune after } \\
\text { spring tea }\end{array}$ & 53.3 & 103.5 & 59.9 & 110.3 & 6.6 & 6.8 \\
\hline
\end{tabular}

Table VI shows the results for pruning in the spring. Both the manually plucked and mechanically plucked buds retain a high density after pruning operations in winter and the density of the tea buds increased by $24 \%$ per annum. For 2 - 3 harvests in each area, tea bud density in winter was not affected by pruning in winter or spring, either for manual or mechanical plucking methods. Table VII shows the results for tea after pruning in winter, to study the yield of tea leaves either for manual or mechanical plucking and compares these with those for significant pruning in spring. After pruning in winter, thinning of the spring buds significantly reduces yield but balancing autumn and winter tea produces less than significant differences.

TABLE VI. A COMPARISON OF THE DENSITY OF TEA SHOOTS FOR DIFFERENT SEASONS IN BUD/900 CM² (SOURCE: AN ADAPTATION OF [9])

\begin{tabular}{|c|c|c|c|c|c|}
\hline \multirow{2}{*}{ Treatment } & \multicolumn{5}{|c|}{ Crop season } \\
\cline { 2 - 6 } & $\begin{array}{c}\text { Spring } \\
\text { tea }\end{array}$ & $\begin{array}{c}\text { Summer } \\
\text { tea }\end{array}$ & $\begin{array}{c}\text { 2nd Summer } \\
\text { tea }\end{array}$ & $\begin{array}{c}\text { Autumn } \\
\text { tea }\end{array}$ & $\begin{array}{c}\text { Winter } \\
\text { tea }\end{array}$ \\
\hline \multicolumn{6}{|c|}{ Manual harvest } \\
\hline $\begin{array}{c}\text { Prune after } \\
\text { winter tea }\end{array}$ & 87.1 & 95.2 & 101.5 & 75.3 & 90.0 \\
\hline $\begin{array}{c}\text { Prune after } \\
\text { spring tea }\end{array}$ & 117.9 & 73.5 & 89.8 & 70.8 & 99.1 \\
\hline \multicolumn{7}{|c|}{ Machine harvest } \\
\hline $\begin{array}{c}\text { Prune after } \\
\text { winter tea }\end{array}$ & 93.9 & 87.2 & 95.4 & 74.7 & 97.3 \\
\hline $\begin{array}{c}\text { Prune after } \\
\text { spring tea }\end{array}$ & 118.9 & 69.1 & 88.8 & 69.6 & 96.9 \\
\hline
\end{tabular}

TABLE VII. A COMPARISON OF THE YIELD OF FRESH TEA LEA LEAVES FOR DIFFERENT PRUNING AND HARVESTING METHODS IN DIFFERENT SEASONS IN KG/40M LENGTH OF TEA BUSH (\%) (SOURCE: AN ADAPTATION OF [9])

\begin{tabular}{|c|c|c|c|c|c|}
\hline \multirow{2}{*}{ Treatment } & \multicolumn{5}{|c|}{ Crop season } \\
\cline { 2 - 6 } & $\begin{array}{c}\text { Spring } \\
\text { tea }\end{array}$ & $\begin{array}{c}\text { Summer } \\
\text { tea }\end{array}$ & $\begin{array}{c}\text { 2nd Summer } \\
\text { tea }\end{array}$ & $\begin{array}{c}\text { Autumn } \\
\text { tea }\end{array}$ & $\begin{array}{c}\text { Winter } \\
\text { tea }\end{array}$ \\
\hline \multicolumn{7}{|c|}{ Manual harvest } \\
\hline $\begin{array}{c}\text { Prune after } \\
\text { winter tea }\end{array}$ & 15.5 & 15.6 & 18.5 & 12.5 & 13.5 \\
$(66.8)$ & $(219.7)$ & $(149.2)$ & $(112.6)$ & $(95.7)$ \\
\hline $\begin{array}{c}\text { Prune after } \\
\text { spring tea }\end{array}$ & 25.0 & 10.3 & 13.8 & 11.8 & 14.7 \\
$(107.8)$ & $(145.0)$ & $(111.3)$ & $(106.3)$ & $(104.3)$ \\
\hline \multicolumn{7}{|c|}{ Machine harvest } \\
\hline $\begin{array}{c}\text { Prune after } \\
\text { winter tea }\end{array}$ & 16.2 & 12.2 & 15.7 & 14.1 & 13.2 \\
\hline Prune after & 23.2 & 7.1 & 12.4 & 11.1 & 14.1 \\
spring tea & $(100.0)$ & $(100.0)$ & $(100.0)$ & $(100.0)$ & $(100.0)$ \\
\hline
\end{tabular}


In order to maintain yield and quality in the Chin Shin Oolong (Camellia sinensis (L.) O. kuntz) tea plantation, shaping operations (pruning) were necessary. To maintain the density and growth of buds and to give an increased yield in spring after the winter tea season partially fermented tea was produced in spring and winter. When the Chin Shin Oolong (Camellia sinensis (L.) O. kuntz) tea plantation underwent shallow pruning, the experimental results show that pruning after spring is more favorable. The total yields for the spring and winter seasons with pruning in winter are $29-37 \%$ greater.

\section{A comparison of the management of manual plucking and machine plucking}

A comparison of the management of tea plantations in the Lugu tea area (manual plucking) and the Mingjian tea area (machine plucking) is considered next. Since 1980, the Mingjian tea area has implemented machine plucking. In this area the altitude is $100-200 \mathrm{~m}$ and the topography is flat. However, in the Lugu tea area tea plucking is still primarily dine manually. In this area the altitude is $300-1,500 \mathrm{~m}$ and the topography is mountainous. The tea plantation working hours and production costs in Mingjian and Lugu tea areas in 1989 are summarized in Table VIII.

TABLE VIII. THE LABOR AND COST FOR TEA PRODUCTION FOR DIFFERENT TYPES OF TEA CULTIVATION (SOURCE: AN ADAPTATION OF [10])

\begin{tabular}{|c|c|c|c|c|}
\hline \multirow{4}{*}{ Items } & \multicolumn{2}{|c|}{ Lugu } & \multicolumn{2}{c|}{ Ming Jian } \\
\cline { 2 - 5 } & $\begin{array}{c}\text { Time } \\
\text { (hour) }\end{array}$ & $\begin{array}{c}\text { Cost of } \\
\text { production } \\
\text { (dollar/ } \\
\text { hectare) }\end{array}$ & $\begin{array}{c}\text { Time } \\
\text { (hour) }\end{array}$ & $\begin{array}{c}\text { Cost of } \\
\text { production } \\
\text { (dollar/ } \\
\text { hectare) }\end{array}$ \\
\hline Weeding* & 582 & 32,837 & 448.6 & 23,269 \\
& $(16.9)$ & $(10.6)$ & $(35.0)$ & $(14.9)$ \\
& $* * *$ & & & 13,417 \\
\hline Fertilizing & 244 & $24,145(7.8)$ & 204 & $(8.6)$ \\
\hline Pest control & $(7.1)$ & & $(15.9)$ & 19,621 \\
& $(10.5)$ & 33,923 & 257 & $(10.9)$ \\
Tea harvest & 2080 & 173,000 & $220.1)$ & 40,400 \\
& $(60.4)$ & $(55.6)$ & $(17.2)$ & $(26.0)$ \\
\hline Others** & 174 & 46,999 & 151 & 58,881 \\
& $(5.1)$ & $(15.1)$ & $(11.7)$ & $(37.9)$ \\
\hline Total & 3,442 & 310,904 & 1280.6 & 155,588 \\
& $(100)$ & $(100)$ & $(100)$ & $(100)$ \\
\hline
\end{tabular}

Note: *, includes weeding, mowing by machine, herbicides and artificial grass. **, includes deep, mulching, pruning, machinery depreciation and maintenance, fuel costs, wages and depreciation, irrigation, irrigation equipment and other operations.

In the Lugu tea area, manual plucking working hours constitute $60.4 \%$ of operation hours and manual plucking accounts for $55.6 \%$ of production costs. In the Mingjian tea area, manual plucking working hours constitute $17.2 \%$ of operation hours and manual plucking accounts for $26.3 \%$ of production costs. Huang [10] determined the cost of plucking tea. In the Mingjian tea area (machine plucking), the cost per hectare was NT\$ 40,400 and in the Lugu tea area (manual plucking) the cost per hectare was NT\$ 173,000 [10]. The wage for manual plucking of fresh leaves was NT\$ 40-60 per kilogram and the cost of machine plucking per hour was NT\$ 1000-1200, giving an average cost per kilogram of NT\$2.5$3.0[10]$.
Huang [10] compared the results for the different production methods and confirmed that the tea harvest accounted for the highest percentage of tea plantation management costs [10]. Therefore, it is concluded that mechanical plucking is more profitable than manual plucking. Over a full year, mechanical plucking significantly reduces production costs.

\section{E. The effect of different plucking methods on yield and operational efficiency}

Huang et al. [11] found that rail type mechanical plucking reduces double type plucking machine labor costs. The tea plantation was pruned in winter and the yield and efficiency for the next year for aril type plucking machine harvest, double type plucking machine and manual plucking were determined [6]. Table IX shows the yield for manually harvested leaves is significantly less than that for a rail type plucking machine or a double type plucking machine. Rail type and double type plucking machine give similar yields. Table $\mathrm{X}$ shows the comparison of the yield of tea shoots and plucking time for a rail type plucking machine, a double type plucking machine and manual plucking. The data only concerns labor, collection and transport costs ignored. Rail type plucking machine harvesting requires only one person and double type plucking machine operations requires two people. Each experimental row was only $30 \mathrm{~m}$ so the rail type plucking machine had to stop and change direction, which increases the operating time.

TABLE IX. A COMPARISON OF THE YIELD OF FRESH TEA (SOURCE: AN ADAPTATION OF [6])

\begin{tabular}{|c|c|c|c|}
\hline \multirow[b]{2}{*}{ Plucking } & \multicolumn{3}{|c|}{ Crop season } \\
\hline & $\begin{array}{l}\text { Spring } \\
\text { crop }\end{array}$ & $\begin{array}{c}\text { Autumn } \\
\text { crop }\end{array}$ & $\begin{array}{l}\text { Winter } \\
\text { crop }\end{array}$ \\
\hline Rail machine & $24.8^{*}$ & 21.4 & 24.0 \\
\hline Double type machine & 23.1 & 24.3 & 22.3 \\
\hline Hand & 15.7 & 17.9 & $15.1^{\vee}$ \\
\hline
\end{tabular}

TABLE $X$. A COMPARISON OF THE YIELD OF TEA SHOOTS AND PLUCKING TIME (SOURCE: AN ADAPTATION OF [6])

\begin{tabular}{|c|c|c|c|c|c|}
\hline Plucking & $\begin{array}{c}\text { Labor } \\
\text { (people) }\end{array}$ & $\begin{array}{c}\text { Time } \\
\text { (hour) }\end{array}$ & $\begin{array}{c}\text { Total } \\
\text { time } \\
\text { (hour) }\end{array}$ & $\begin{array}{c}\text { Total } \\
\text { time per } \\
\text { hectare } \\
\text { (hour) }\end{array}$ & $\begin{array}{c}\text { Cost of } \\
\text { harvest } \\
\text { (NT\$) }\end{array}$ \\
\hline $\begin{array}{c}\text { Rail } \\
\text { machine }\end{array}$ & 1 & 0.42 & 0.42 & 23.3 & 6,990 \\
\hline $\begin{array}{c}\text { Double type } \\
\text { machine }\end{array}$ & 2 & 0.20 & 0.40 & 22.2 & 6,660 \\
\hline Hand & 16 & 1.57 & 25.12 & 1359.6 & 140,000 \\
\hline
\end{tabular}

Hung et al. [11] suggested increasing the length of the tea row to reduce the overall operating time by reducing mechanical shutdown and changes of direction. Table X shows that the harvest weight of fresh leaves for the rail type plucking machine and double type plucking machine are both significant higher than that for manual plucking, mainly because manually plucked tea plantations have a lower growth density. There is no significant difference in the density of tea buds and the harvest weights between the rail type plucking machine harvest and a double type plucking machine harvest. Lee [12] used imported semi-self-propelled and self-propelled plucking machine in a tea plantation to reduce the physical burden on the 
operator, but this requires the coordination of two people. The efficiency and effectiveness are no greater than that for a double type plucking machine. These two types of plucking machines impose restrictions on the width, slope and length of rows and a self-propelled plucking machine is expensive, so it is not generally feasible. A self-propelled plucking machine was found to be suitable only for long rows with minimal gradient. The cost of self-propelled plucking machine machines is now \$NT 1,000,000-4,000,000 and there is an additional need to allot the space for mechanical rotating operations, so they are only suitable for very large tea plantations.

\section{CONCLUSIONS}

Harvesting tea involves a large expenditure on seasonal labor. Labor shortages in the labor and an aging workforce mean that traditional manual plucking of tea leaves must be replaced by mechanical plucking. The mechanical plucking of tea leaves is quite common in Japan and Argentina. The mechanical plucking of tea leaves has been used for many years and the mechanical plucking technology has improved in the Mingjian tea area of Nantou, Taiwan. China, Sri Lanka and India are also currently mechanically plucking tea leaves. The mechanical plucking of tea leaves of tea gives 8-15 time better harvesting efficiency than manual harvesting. Compared with manual plucking, mechanical plucking reduces production costs by $50-70 \%$. Mechanical plucking also leads to time saving and superior quality since tea leaves arrive in less time (and thus are fresher) to the factory. However, it should be noted that manual plucking causes fewer tea leaves to be lost during plucking, and thus improves tea quality, and that mechanical plucking requires a pre-classification of tea leaves to get a superior quality tea.

In order to reduce the production costs and to address the labor shortage in Taiwan, the development of the mechanical plucking of tea leaves is inevitable. However, machine plucking over a long time, causes the tea buds to germinate and there is an excessive increase in density. Tea leaves with a density greater than $900 \mathrm{~cm}^{2}$ have more than 140 buds and the shoot is thin. This causes the tea buds to develop facing-leaves, the leaves become thin and tea quality is reduced. Therefore, during the tea leaf harvest, there must be an appropriate control of the mechanical blade and suitable pruning operations. In the future, tea plantations that use mechanical plucking will require more planning of the selection of the correct tea variety and cultivator, deep plowing, fertilization, irrigation, disease and pest management, tree crown pruning, machinery and tea manufacturing techniques so that the tea is robust vigorous and has an even branch size and distribution. The tea bud germination density must be appropriate and there must be tidy growth, to allow mechanical plucking and to maintain tea leaf quality.

Mechanized tea plucking in Taiwan will require coordination between tea plantations and automation, so that production costs are reduced and competitiveness is improved. To increase mechanization, the agricultural authorities must provide mechanical means and management technology and assistance for machine purchases by farmers, to ensure that the Taiwanese tea industry remains internationally competitive and to allow sustainable development.

\section{References}

[1] Z. F. Mao, D. B. Chen, "Discussion of the excellent tea on plucking mechanized” , China Tea, Vol. 3, No. 1, pp. 4-5, 2006

[2] S. L. Tsai, China encyclopedia of agriculture, Tea Volumes, Agriculture Publishing House, Beijing, China, pp. 7-8, 1988

[3] Z. M. Chen, Zhong-guo chajing, Shanghai Culture Publishing House, Shanghai, China. pp. 353-354, 1992

[4] Y. Han, H. Xiao, G. Qin, Z. Song, W. Ding, S. Mei, "Developing situations of tea plucking machine”, Engineering, Vol. 6, pp. 268-273, 2014

[5] J. M. Chang, "A study of effect on the growth and quality of tea bush with mechanical plucking”, Journal of Chinese Agricultural Engineering, Vol. 12, No. 1, pp. 1-10, 1996

[6] C. L. Lee, T. F. Huang, "Development and application of rail management system for tea field management machines”, Taiwan Tea Research Bulletin, Vol. 19, pp. 29-36, 2000

[7] J. M. Chang, "The province of implemented general situation on tea garden mechanization ”, Tea Newsletter, Vol. 346, pp. 87, 1971

[8] T. F. Huang, C. L. Lee, Y. K. Chang, "Study and extension on mechanical plucking of hand plucking tea area”, Taiwan Tea Research Bulletin, Vol. 5, pp. 15-30, 1986

[9] C. L. Lee, “Technical improvement mechanical plucking in Chin-shin oolong tea garden- Effects of plucking periods and depths on tea yields of different tea crop seasons”, Taiwan Tea Research Bulletin, Vol. 10, pp. $115-127,1991$

[10] T. F. Huang, "Development of hand-pluck tea garden mechanized in the future”, Development and Promotion of Taiwan Tea research Seminars Monograph. Taoyuan, Taiwan, pp. 38-43, 2001

[11] T. F. Huang, C. L. Lee, Y. K. Chang, "Study on using the rail mechanical plucking management system in hand plucking tea area", Taiwan Tea Research Bulletin, Vol. 22, pp. 79-86, 2003

[12] C. L. Lee, "Study and promotion on tea plucking mechanization”, Tea Production Technology Seminars Monograph, Taoyuan, Taiwan, pp. 115-124, 1992 